\title{
A Study on Cotton (Gossypium sp.) Nectar Production in Uzbekistan
}

\author{
G'ulom Hamidovi1, Qodirjon Maxsudov ${ }^{\left({ }^{1} \text {, }\right.}$, Shahzoda Voxobova ${ }^{(1,}$ \\ Dilyora Akramova 1
}

${ }^{1}$ Department of Biology, Natural Sciences Faculty, Fergana University, Fergana, Uzbekistan

\begin{abstract}
Given the importance of cotton varieties in beekeeping, we have been able to determine the nectar and honey yield per hectare for several years Cotton nectaries produce highly concentrated carbohydrates, nectarines, amino acids and fatty acids. Unlike other types of plants. In different varieties of cotton, there are 4 types of nectaries (intra-cup, bract, sub-bract, and leaf), and the number and concentration of nectarium are different for all types. Nectar productivity of fine fiber varieties is significantly higher than that of medium fiber varieties. Nectar is an important nutrient source for insects and pathogens due to its high sugar content. Several methods of nectar determination were used to determine the number of angles of cotton varieties planted in the country, such as "tube" and "washing." On average, honey yield of these varieties is $50-60 \mathrm{~kg}$ per hectare. It is understood from the research results that cotton varieties have high honey and nectar productivity in Uzbekistan environment.
\end{abstract}

\section{ARTICLE HISTORY}

Received: April 03, 2020

Revised: July 03, 2020

Accepted: September 20, 2020

\section{KEYWORDS}

Cotton varieties,

Nectar,

Nectar Concentration,

Test Method,

Washing Method

\section{INTRODUCTION}

Cotton (Gossypium sp.) is an important source of feed for beekeeping farms in Uzbekistan. Because currently the main source of beekeeping honey is cotton fields, along with natural flora. However, the data on the cotton crop is not quite complete. Also, many new varieties of cotton have been released lately and the amount of wreaths has not been determined. Therefore, this issue is of great importance both in cotton growing and beekeeping. Despite many scientific observations and experiments, so far there is no consensus on the amount of cotton flower juice in science. It is known that nectar extinction is a complex biological process that is influenced by climatic conditions of the year and by anthropogenic factors. Although cotton has been planted since ancient times, its "originality" has only been relatively recent. At first it was not known whether cotton produced nectar or not. Beekeeping was observed later in the cotton flowers. It is determined by the yield of the flower [1-3].

Kaziev's research shows that the yield of cotton in the conditions of Azerbaijan in 1964 is 26-37 kg. [4]. According to SG Minkov [5], in South Kazakhstan each flower produces honey $8-11 \mathrm{mg}$ and its honey yield is from 11 to $33 \mathrm{~kg}$ per hectare. Also, the amount of cotton wool

CONTACT: Qodirjon Maxsudov $₫$ makhsudov79@inbox.ru $\equiv$ Department of Biology, Natural Sciences Faculty, Fergana University, Fergana, Uzbekistan 
was calculated in Bulgaria and Egypt. According to their data, in each of these countries each flower produces 8-12 $\mathrm{mg}$ from rose. Their honey yield ranges from 20 to $30 \mathrm{~kg}$ [6].

Cotton nectaries produce highly concentrated carbohydrates, nectarins, amino acids and fatty acids [7, 8]. Nectar is an important nutrient source for insects and pathogens due to its high sugar content [9-12]. Cotton nectar attracts insects beneficial for pollination and protection, which enable the plants to achieve greater reproduction [13].

\section{MATERIAL and METHODS}

Objects of the research are the following cotton varieties: cotton "Namangan-77", created by VA Avtonomov, M. Saidakhmedov, A. Egamberdiev and others at the Scientific Research Institute of Agrotechnologies of Crop Breeding and Breeding. The average growth period is 100-120 days and included in the State Register since 2012. Sh.Namazov, N.Khojambergenov and others at the Sulton Scientific Research Institute of Crop Breeding, Seed Breeding and Agro-Technology. The ripening period is 115-120 days on average and has been included in the state register since 2011. "Andijan 35" was developed by T.Komilov and others at the Andijan scientific experimental station of the Scientific- Research Institute of Crop Breeding, Seeding and Breeding Agrotechnology. The ripening period is 122-255 days on average and is included in the 2006 State Register.

Several methods of nectar determination were used to determine the number of angles of cotton varieties planted in the country, such as "tube" and "washing." The tube technique is simple and easy to use and has been used by many people. The number of angles determined by the tube method is as follows. Glass tubes of $0.1-0.3 \mathrm{~mm}$ in diameter and $4.5 \mathrm{~cm}$ in length are manufactured. They are weighed on accurate weights and weighed. These tubes are transmitted between plant florets and extracted from the juice. It will be weighed again. Of course, the number of flowers and what candies are derived. The amount of sugar in the rose (in percentage) is determined by the refractometer. The second method is the "washing" method where distilled water is poured into specially prepared tubes $\left(40 \mathrm{~cm}^{3}\right)$. These vials are given a certain amount of flowers. The filtrate is shaken for 20-25 minutes when the juice from the flowers is transferred to the vial. The filtrate is analyzed by the Hagedorn and Jensen [14] method in the chemical laboratory.

\section{RESULTS and DISCUSSION}

Cotton blooming in Uzbekistan lasts from early July until late autumn, and slower flowering lasts from mid-July to late August. Vegetation buds begin to open at 8-9 am, slopes begin at 10 am and last until the evening. As you know, all of cottons produces nectar. According to our observations, the intensity of the hernia separation lasts from the morning to the middle of the day. In a study, Gilliam et al. [15]. Floral nectar from 3 cultivars of fieldgrown cotton, 9 cultivars of cotton grown in a greenhouse, 5 cultivars of citrus, saguaro cactus, and prickly pear cactus were examined for bacteria, yeasts, and molds by plating on selective microbiological media. No microbes were isolated from nectar of any cotton flowers. Of 23 samples of citrus nectar, 3 contained a few gram-negative rod-shaped bacteria. Nectar from prickly pear cactus contained no microbes, although nectar from saguaro cactus contained a few bacteria (gram-negative rods, gram-positive rods, and gram-positive cocci). These results are discussed in relation to possible antimicrobial substances in nectar as well as the origin of the microflora of honey bees.

To our knowledge, the amino acids in the floral nectar of cotton (Gossypium spp.) have not been determined, although Clark and Ulkefahr [16], using paper chromatography, failed to find amino acids in Gossypium extrafloral nectar. However, Mound [17] detected two ninhydrin-positive substances on paper chromatograms of extrafloral nectar from $G$. 
barbadense L., and Hanny and Elmore [18], using both gas and thin layer chromatography, found 24 free amino acids in extrafloral nectar of G. hirsutum L. Yokohama [19], without giving data, stated that she found a high concentration of amino acids in extrafloral nectar of $G$. hirsutum.

Given the importance of cotton varieties in beekeeping, we have been able to determine the nectar and honey yield per hectare for several years (Table 1). It was found that the amount of nectar in each flower ranges from 8-10 to $30-36 \mathrm{mg}$. The amount of honey per hectare is $30-$ $50 \mathrm{~kg}$ and honey yield is $15-20 \mathrm{~kg}$ to $30-40 \mathrm{~kg}$.

Table 1. Nectar productivity of different medium fiber varieties.

\begin{tabular}{ccccc}
\hline No & Cotton varieties & $\begin{array}{c}\text { The amount of } \\
\text { nectar per flower }(\mathrm{mg})\end{array}$ & $\begin{array}{c}\text { Nectar } \\
\text { productivity kg/hectares }\end{array}$ & $\begin{array}{c}\text { Honey product } \\
\text { kg/hectares }\end{array}$ \\
\hline 1 & Bukhora-102 & $26.10 \pm 3.40$ & 33.47 & 24.85 \\
2 & Andijan-36 & $11.75 \pm 1.34$ & 35.60 & 16.20 \\
3 & C-8286 & $10.32 \pm 1.16$ & 30.04 & 15.71 \\
4 & C-6524 & $9.66 \pm 1.13$ & 25.92 & 16.10 \\
5 & C-9063 & $12.66 \pm 1.81$ & 33.04 & 21.10 \\
\hline
\end{tabular}

From the above, it can be seen from the fact that mid-fiber varieties are an important nectar-honey source for beekeeping farms. Therefore, all cotton plantations should be used on time.The nectar extraction of the pellets of cotton (Table 2) differs from each other. As shown in the table, the most widespread of medium-fiber varieties are produced by shellfish $(74 \%)$, while others range from $3 \%$ to $14 \%$. At the same time, the abdominal cavity accounted for $84 \%$, and at least the leaflet $(1.18 \%)$.

Table 2. Sugar yield of different types (\%)

\begin{tabular}{cccc}
\hline \multirow{2}{*}{ No } & \multirow{2}{*}{ Part } & \multicolumn{2}{c}{ Sugar contents (mg) } \\
\cline { 3 - 4 } & & Medium fiber varieties & Varieties of fine fibers \\
\hline 1 & Inside the flowerpot & $25.9(74 \%)$ & $54.90(84 \%)$ \\
2 & Underneath the skull & $3.15(9 \%)$ & $6.94(11 \%)$ \\
3 & In front of the flowerpot & $5.08(14 \%)$ & $2.00(3 \%)$ \\
4 & On the leaf & $1.12(3 \%)$ & $1.18(2 \%)$ \\
5 & Total & $35.25(100 \%)$ & $65.02(100 \%)$ \\
\hline
\end{tabular}

The most productive of cotton candy is the pearl inside the turquoise. Based on this, we have identified the dynamics of the wreath, which is separated by the apple tree in the flowerpot: (Table 3). Cotton plants present a relevant model system for comparing the defence strategies against herbivores [20]. While a lot of research has been carried out about the biochemical mechanisms underlying VOC emission in cotton plants and their associated benefşsşal interactions with insects [21], very little is known about the role of nectar [22]. Results of Llandres's study showed that wild cotton varieties produced a greater quantity of nectaries and this nectaries enhanced the diversity of natural enemies. The amount of nectar excreted by the entrails also varies. Accordingly, the number of bees that visit them varies. In another study, Özkök and Silici [20] performed biological analyses of different honey samples (chestnut, citrus, clover, cotton and sunflower). According to their results, cotton honey has $38.99 \pm 5.08$ mg GAE/100 g sample total phenolic content, and also it posses $139.95 \pm 4.52 \mathrm{mg}$ AAE/g sample antioxidant activity and \%6.67 \pm 0.42 antiradical activity [23]. As noted earlier, nectar and honey yield of fine fibers is much higher than that of medium-fiber varieties. It is reported that the honey yield of the previously planted and cultivated fine-fiber varieties in the country 
ranges from $43.68 \mathrm{~kg}$ to $100 \mathrm{~kg} / \mathrm{ha}$. The most productive varieties are Bukhara-1, Termez-7. The S-6040, Surxon-2 can be cited. On average, honey yield of these varieties is 50-60 kg per hectare.

Table 3. The process of separation of the wreath by the giraffe inside the turquoise

\begin{tabular}{|c|c|c|c|c|c|c|c|}
\hline \multirow[b]{3}{*}{ Time } & \multirow{3}{*}{$\begin{array}{c}\text { Air } \\
\text { temperature } \\
\left({ }^{\circ} \mathrm{C}\right)\end{array}$} & \multicolumn{6}{|c|}{ Varieties } \\
\hline & & \multicolumn{2}{|c|}{ Namangan-77 } & \multicolumn{2}{|c|}{ Sulton } & \multicolumn{2}{|c|}{ Andijan-35 } \\
\hline & & $\begin{array}{l}\text { Nectar } \\
\text { content } \\
(\mathrm{mg})\end{array}$ & $\begin{array}{c}\text { Nectar } \\
\text { concentration } \\
(\%)\end{array}$ & $\begin{array}{c}\text { Nectar } \\
\text { content (mg) }\end{array}$ & $\begin{array}{c}\text { Nectar } \\
\text { concentration } \\
(\%)\end{array}$ & $\begin{array}{l}\text { Nectar } \\
\text { content } \\
(\mathrm{mg})\end{array}$ & $\begin{array}{c}\text { Nectar } \\
\text { concentratio } \\
n\end{array}$ \\
\hline 7 & 24 & $1.80 \pm 0.21$ & 20 & $0.30 \pm 0.06$ & 15 & $1.33 \pm 0.18$ & 43 \\
\hline 9 & 27 & $12.32 \pm 3.12$ & 22 & $2.22 \pm 0.45$ & 30 & $3.66 \pm 0.48$ & 43 \\
\hline 13 & $3 \overline{6}$ & $\overline{4} \overline{6} . \overline{0} \pm \pm \overline{7} .18$ & 30 & $8.50 \pm 1.19$ & $\overline{4} \overline{2}$ & $7.33 \pm 1.10$ & 50 \\
\hline 15 & 35 & $11.00 \pm 2.71$ & 35 & $10.00 \pm 1.31$ & 45 & $13.66 \pm 3.14$ & 53 \\
\hline 17 & 35 & $7.03 \pm 0.94$ & 45 & $10,50 \pm 1,32$ & 47 & $12 \pm 3.12$ & 52 \\
\hline 19 & 32 & $7.00 \pm 0.94$ & 45 & $8.00 \pm 1.12$ & 47 & $9.20 \pm 1.29$ & 53 \\
\hline Aver & & 10.18 & 31.71 & 6.24 & 37.54 & 5.02 & 47 \\
\hline
\end{tabular}

\section{CONCLUSION}

In conclusion, it is important to note that cotton varieties sown in all regions of Uzbekistan are an important source of nutrition for beekeeping farms. Cotton nectar attracts insects beneficial for pollination and protection, which enable the plants to achieve greater reproduction. According to our observations, the intensity of the hernia separation lasts from the morning to the middle of the day. At the same time, timely pollination of cotton varieties with bees is an important factor in increasing their productivity.

\section{Declaration of Conflicting Interests and Ethics}

The authors declare no conflict of interest. This research study complies with research publishing ethics. The scientific and legal responsibility for manuscripts published in IJSM belongs to the author(s).

\section{Orcid}

G'ulom Hamidov (D) https://orcid.org/0000-0002-0599-7562

Qodirjon Maxsudov (i) https://orcid.org/0000-0002-1345-3936

Shahzoda Voxobova (D) https://orcid.org/0000-0002-5203-3483

Dilyora Akramova (D) https://orcid.org/0000-0002-1827-4304

\section{REFERENCES}

[1]. Layok, V. D. ( 1941). Kulturnıye medonosı Uzbekstana i rol pçelv povışenii ix urojaynosti (Tekst)/pod red. Akad. R.R.Şedreva-Taşkent: Uzgiz. pp. 68.

[2]. Eskov, E. K. (1992). Etologiya medonosnoy pçell. Moskova, Kolos, pp. 336.

[3]. Hamidov, G. H. (1977) Beekeeping and cotton growing. Tashkent, pp. 132.

[4]. Kaziev, T. I. (1964). Problems of nectar secretion in cotton and the role of honey bees in increasing its vield. Baku, Azerb. Gos. İzdat. pp. 215.

[5]. Minkov, S. G. (1957). Nectar productivity of cotton in South-Kazakh region. Pchelovodstvo, 34(12), 35-40.

[6]. Radoev, L. (1963). Studies on bee pollination and honey productivity of cotton. In $19^{\text {th }}$ Internatl. Apic. Cong. Proc. Liblise, Czechoglovaciya. pp.99.

[7]. Bulgakova, L. L. (1978). Medonosnaya rastitelnost pribrejnoy zonı srednogo teçeniya peki Strdarl. Avtoreferat dis. Kand. Biol. Nauk. Taşkent, pp. 19. 
[8]. Anton, S., Komon, J. E., Denisow, B. (2017). Floral nectary, nectar production dynamics and chemical composition in five nocturnal Oenothera species (Onagraceae) in relation to loral visitors. Planta, 246, 1051-1067. https://doi.org/10.1007/s00425-017-2748-y

[9]. Heil, M. (2011). Nectar: Generation, regulation, and ecological functions. Trends in Plant Science, 16, 191-200. https://doi.org/10.1016/j.tplants.2011.01.003

[10]. Chalcoff, V. R., Aizen, M. A., \& Galetto, L.(2006). Nectar concentration and composition of 26 species from the temperate forest of South America. Annals of Botany, 97, 413-421. https://doi.org/10.1093/aob/mcj043

[11]. Knopper, L. D., Dan, T., Reisig, D. D., Johnson, J. D., \& Bowers, L. M. (2016). Sugar concentration in nectar: A quantitative metric of crop attractiveness for refined pollinator risk assessments. Pest Management Science, 72, 1807-1812. https://doi.org/10.1002/ps. 4321

[12]. Nicolson, S.W. (2007). Nectar consumers. In S. W. Nicolson, M. Nepi, \& E. Pacini (Eds.), Nectaries and nectar. Dordrecht, The Netherlands: Springer. pp. 289-342. ISBN 978-1-4020-5937-7

[13]. Gonzalez-Teuber, M., Silva-Bueno, J.C., Heil, M., \& Boland, W. (2012). Increased host investment in extrafloral nectar (EFN) improves the efficiency of a mutualistic defensive service. PLoS One, 7, e46598. https://doi.org/10.1371/journal.pone.0046598

[14]. Hanes, C. S. (1929). An application of the method of Hagedorn and Jensen to the determination of larger quantities of reducing sugars. Biochem J., 23(1), 99-106. https://doi.org/10.1042/bj0230099

[15]. Gilliam, M., Moffet, J. O., Kauffeld N. M. (1983). Examination of floral necta of citrus, cotton, and Arizona desert plants for microbes. Apidologie, 14(4), 299-302. https://doi.org/10.1051/apido:19830403

[16]. Clark, E. W., Lukefahr, M. J. (1956). A partial analysis of cotton extrafloral nectar and its approximation. Journal of Economic Entomology, 49 (6), 875-876. https://doi.org/10.10 93/jee/49.6.875

[17]. Mound, L. A. (1962). Extrafloral nectaries of cotton and their secretions. Emp. Cotton Grow. Rev., 39, 254-261. https://doi.org/10.1093/jxb/34.2.103

[18]. Hanny, B. W., Elmore, C. D. (1974). Amino acid composition of cotton nectar. Agr. Food Chem., 22, 476-478. https://doi.org/10.1021/jf60193a038

[19]. Yokohama, V. Y. (1978). Relation of seasonal changes in extrafloral nectar and foliar protein and arthropod. Environmental Entomology, 7(6), 799-802. https://doi.org/10.109 3/ee/7.6.799

[20]. Llandres, A.L., Verdeny-Vilalta, O., Jean, J., Goebel, F. R., Seydi, O., Brévault, T. (2019). Cotton extrafloral nectaries as indirect defence against insect pests. Basic and Applied Ecology, 37, 24-34.

https://doi.org/10.1016/j.baae.2019.05.001

[21]. Hagenbucher, S., Olson, D. M., Ruberson, J. R., Wäckers, F. L., Romeis, J. (2013). Resistance mechanisms against arthropod herbivores in cotton and their interactions with natural enemies. Critical Reviews in Plant Sciences, 32 (6), 458-482. https://doi.org/10.1080/07352689.2013.809293

[22]. Grasso, D. A., Pandolfi, C., Bazihizina, N., Nocentini, D., Nepi, M. S. (2015). MancusoExtrafloral-nectar-based partner manipulation in plant-ant relationships. AoB Plants, 7. https://doi.org/10.1093/aobpla/plv002 
[23]. Özkök, D., Silici, S. (2018). Effects of crystallization on antioxidant property of honey. Journal of Apitherapy, 3(2), 24-30.

https://doi.org/10.5455/ja.20180607113134 